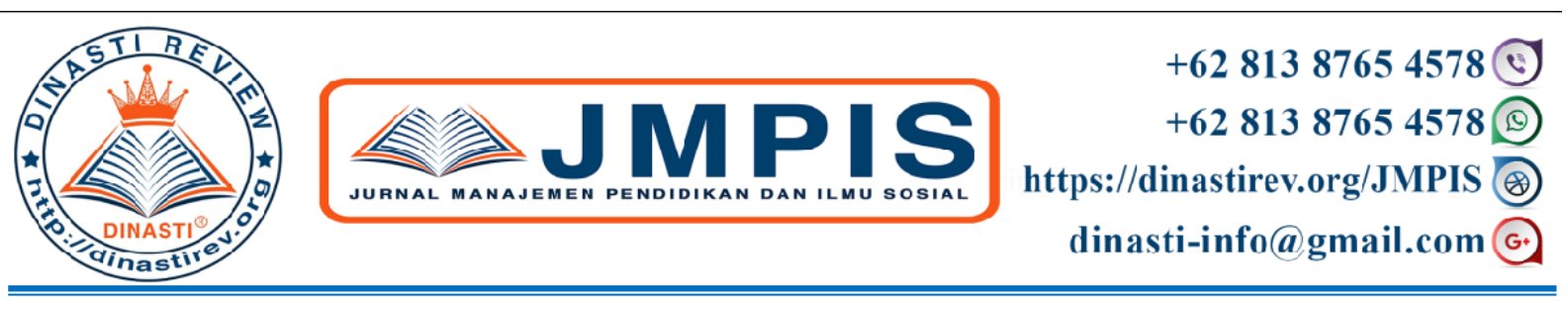

\title{
PENGARUH MOTIVASI BELAJAR, DISIPLIN BELAJAR, DAN \\ LINGKUNGAN TEMAN SEBAYA TERHADAP HASIL BELAJAR EKONOMI SISWA KELAS XI IPS SMAN TITIAN TERAS
}

\author{
Khairinal $^{1}$, Farida Kohar ${ }^{2}$, Dina Fitmilina ${ }^{3}$ \\ 1) Dosen Universitas Jambi, Jambi, Indonesia \\ ${ }^{2)}$ Dosen Universitas Jambi, Jambi, Indonesia \\ 3) Alumni Program Studi Magister Pendidikan Universitas Jambi, Jambi, Indonesia
}

\begin{tabular}{|c|c|}
\hline $\begin{array}{c}\text { ARTICLE INFORMATION } \\
\text { Received: } 24 \text { Juni } 2020 \\
\text { Revised: } 30 \text { Juni } 2020 \\
\text { Issued: } 10 \text { Juli } 2020 \\
\text { Corresponding author: first } \\
\text { author } \\
\text { E-mail: } \\
\text { khairinal164@gmail.com } \\
\text { faridakohar2015@gmail.com } \\
\text { dinafitmilina@gmail.com }\end{array}$ & $\begin{array}{l}\text { Abstract: Penelitian ini mengkaji mengenai hasil belajar siswa } \\
\text { yang dipengaruhi oleh motivasi belajar, disiplin belajar, dan } \\
\text { lingkungan teman sebaya.Metode penelitian menggunakan } \\
\text { pendekatan kuantitatif deskriptif yang dilakukan melalui survei } \\
\text { dengan teknik pengumpulan data menggunakan angket.Populasi } \\
\text { dan sampel adalah seluruh siswa kelas XI IPS tahun ajaran } \\
2019 / 2020 \text { sebanyak } 72 \text { siswa. Pengolahan data menggunakan } \\
\text { bantuan aplikasi statisticSPSS } 20.0 \text { for windows. Penelitian ini } \\
\text { bertujuan untuk (1) untuk mengetahui pengaruh motivasi belajar } \\
\text { terhadap hasil belajar siswa, (2) untuk mengetahui pengaruh } \\
\text { disiplin belajar terhadap hasil belajar siswa (3) untuk } \\
\text { mengetahui pengaruh lingkungan teman sebaya terhadap hasil } \\
\text { belajar siswa (4) untuk mengetahui pengaruh secara simultan } \\
\text { motivasi belajar, disiplin belajar dan lingkungan teman sebaya } \\
\text { terhadap hasil belajar siswa. Hasil penelitian menyimpulka: (1) } \\
\text { Motivasi belajar memiliki pengaruh terhadap hasil belajar siswa } \\
\text { sebesar 0.385, thitung > t tabel yaitu 3.726>1.666, (2) Disiplin } \\
\text { belajar memiliki pengaruh terhadap hasil belajar siswa sebesar } \\
\text { 0.283,t hitung }>\text { t tabel yaitu } 2.671>1.666 \text {, (3) Lingkungan } \\
\text { teman sebaya memiliki pengaruh terhadap hasil belajar siswa } \\
\text { sebesar 0.265, t hitung > t tabel yaitu } 2.434>1.666 \text {, (4) Secara } \\
\text { simultan motivasi belajar, disiplin belajar, dan lingkungan teman } \\
\text { sebaya memiliki pengaruh terhadap hasil belajar siswa sebesar } \\
\text { 0.373, dengan taraf signifikan 0.000. Kesimpulan pada } \\
\text { penelitian ini adalah terdapat pengaruh antara motivasi belajar, } \\
\text { disiplin belajar dan lingkungan teman sebaya terhadap hasil } \\
\text { belajar ekonomi kelas XI IPS SMAN Titian Teras. } \\
\text { Keyword: Motivasi Belajar, Disiplin Belajar, Lingkungan } \\
\text { Teman Sebaya, Hasil Belajar. }\end{array}$ \\
\hline
\end{tabular}

\section{PENDAHULUAN}

Dalam keseluruhan proses pendidikan, kegiatan belajar dan mengajar merupakan kegiatan yang pokok. Hal ini berarti bahwa berhasil tidaknya pencapaian tujuan pembelajaran tergantung bagaimana proses belajar mengajar dirancang dan dijalankan. Tujuan dari setiap pembelajaran adalah memperoleh hasil belajar yang optimal. Menurut Sardiman (2001:55) dalam pendidikan dan pengajaran, tujuan dapat diartikan sebagai suatu usaha untuk memberikan rumusan hasil yang diharapkan dari siswa atau subjek belajar, setelah memperoleh pengalaman belajar. 
Hasil belajar dalam suatu lembaga pendidikan merupakan indikator pencapaian nilai siswa. Begitu pula hasil belajar mata pelajaran ekonomi yang terdapat pada SMA. Tetapi tidak bisa dipungkiri bahwa hasil belajar banyak dipengaruhi juga oleh faktor-faktor lain di samping pengajaran yang dilakukan oleh guru. Salah satu faktor yang mempengaruhi hasil belajar yaitu motivasi belajar, motivasi belajar yang tinggi dapat membuat peserta didik memiliki dorongan untuk mencapai hasil belajar yang optimal. Menurut Djamarah (2011:148). "Motivasi sangat diperlukan dalam proses belajar, sebab seseorang yang tidak mempunyai motivasi dalam belajar, tidak akan mungkin melakukan aktivitas belajar".

Secara umum menurut Sudjana (2005: 39) faktor-faktor yang mempengaruhi keberhasilan belajar itu dapat dibagi menjadi dua bagian yaitu faktor internal dan faktor eksternal. Faktor internal merupakan faktor dari dalam diri siswa, yang meliputi kemampuan yang dimilikinya, seperti motivasi belajar, minat dan perhatian, disiplin, sikap dan kebiasaan belajar, ketekunan, sosial ekonomi, faktor fisik dan psikis. Faktor eksternal merupakan yang datang dari luar diri siswa atau faktor lingkungan, terutama kualitas pengajaran. Disiplin belajar siswa merupakan faktor yang juga penting untuk dikaji dan diteliti lebih mendalam pengaruhnya terhadap hasil belajar, sebab dengan adanya disiplin belajar yang tinggi dari diri siswa maupun sekolah maka akan berpengaruh terhadap hasil dari siswa tersebut. Selain itu lingkungan sosial siswa khususnya teman sekelas (teman sebaya) memiliki pengaruh terhadap hasil belajar siswa. Faktor yang begitu penting namun sering luput dari perhatian para guru dan para orang tua adalah peranan teman sebaya.

Siswa kelas XI IPS SMA Negeri Titian Teras menurut pengamatan peneliti dari awal semester ganjil tahun pelajaran 2019/2020 motivasi belajar pada mata pelajaran ekonomi masih belum optimal, dapat dilihat dari beberapa siswa dalam mengerjakan tugas kurang tepat waktu dan berhubungan dengan disiplin belajar, masih terdapat juga siswa yang terlambat datang ke kelas dengan berbagai alasan dan mudah terpengaruh oleh teman sebayanya di dalam kelas. Selain itu dengan dilakukan penelitian ini berharap dapat menemukan solusi untuk memperbaiki sikap dan perilaku siswa terkait motivasi, kedisiplinan dan lingkungan teman sebaya agar hasil belajar yang dicapai siswa dapat optimal. Kemudian bagaimana pengaruh dari motivasi, disiplin dan lingkungan teman sebaya tersebut terkait dengan hasil belajar siswa.

Berdasarkan latar belakang yang telah dipaparkan di atas, maka peneliti tertarik untuk mengadakan penelitian lebih lanjut tentang "Pengaruh Motivasi Belajar, Disiplin Belajar, dan Lingkungan Teman Sebaya terhadap HasilBelajar Ekonomi Siswa Kelas XI IPS SMAN Titian Teras".

Berdasarkan permasalahan yang telah diuraikan sebelumnya, adapun tujuan-tujuan yang akan di capai dalam penelitian ini yaitu: 1) Untuk mengetahui pengaruh motivasi belajar terhadap hasil belajar ekonomi siswa; 2) Untuk mengetahui pengaruh disiplin belajar terhadap terhadap hasil belajar ekonomi siswa; 3) Untuk mengetahui pengaruh lingkungan teman sebaya terhadap hasil belajar ekonomi siswa; dan 4) Untuk mengetahui pengaruh motivasi belajar, disiplin belajar, dan lingkungan teman sebaya terhadap hasil belajar ekonomi siswa kelas XI IPS SMAN Titian Teras.

\section{KAJIAN PUSTAKA}

\section{Hasil Belajar}

Hasil belajar menurut Hamalik (2003: 155) tampak sebagai terjadinya perubahan tingkah laku pada diri seseorang yang dapat diamati dan diukur bentuk perubahan pengetahuan, sikap dan keterampilan. Perubahan tersebut diartikan sebagai terjadinya peningkatan dan pengembangan yang lebih baik dibandingkan sebelumnya, misalnya dari tidak tahu menjadi tahu. Hasil belajar ini berupa nilai yang nantinya menjadi indikator apakah tujuan pembelajaran telah tercapai atau 
belum. Hasil belajar bersifat kompleks dan dapat berubah-ubah.

Dalyono (1997: 55) berhasil tidaknya seseorang dalam belajar disebabkan oleh dua faktor, yaitu faktor internal dan faktor eksternal sebagai berikut. 1) faktor internal (yang berasal dari dalam diri orang yang belajar) seperti kesehatan, intelegensi dan bakat, minat dan motivasi, serta cara belajar. 2) faktor eksternal (yang berasal dari luar diri orang belajar) seperti keluarga, sekolah, masyarakat, dan lingkungan sekitar.

Indikator utama hasil belajar siswa adalah 1) Ketercapaian daya serap terhadap bahan pembelajaran yang diajarkan, baik secara individual maupun kelompok. Pengukuran ketercapaian daya serap ini biasanya dilakukan dengan penetapan Kriteria Ketuntasan Belajar Minimal $(\mathrm{KKM}), 2)$ Perilaku yang digariskan dalam tujuan pembelajaran telah dicapai oleh siswa, baik secara individual maupun kelompok.

\section{Motivasi Belajar}

Menurut Clayton Alderfer (Hamdu, 2011: 10) motivasi belajar adalah kecenderungan siswa dalam melakukan kegiatan belajar yang didorong oleh hasrat untuk mencapai prestasi atau hasil belajar sebaik mungkin. Motivasi dipandang sebagai dorongan mental yang menggerakkan dan mengarahkan perilaku manusia, termasuk perilaku belajar. Dalam motivasi terkandung adanya keinginan yang mengaktifkan, meggerakkan, menyalurkan, dan mengarahkan sikap serta perilaku pada individu belajar.

Menurut Uno (2015:34) menyatakan bahwa beberapa teknik motivasi yang dapat dilakukan dalam pembelajaran sebagai berikut: 1) Pernyataan penghargaan secara verbal, 2) Menggunakan nilai ulangan sebagai pemacu keberhasilan, 3) Menimbulkan rasa ingin tahu, 4) Memunculkan sesuatu yang tidak diduga oleh siswa, 5) Menjadikan tahap dini dalam belajar mudah bagi siswa, 6) Menggunakan materi yang dikenal siswa sebagai contoh dalam belajar, 7) Gunakan kaitan yang unik dan tak terduga untuk menerapkan suatu konsep dan prinsip yang telah dipilih, 8) Menuntut siswa untuk menggunakan hal-hal yang telah dipelajari sebelumnya, 9) Menggunakan simulasi dan permainan, 10) Memberikan kesempatan kepada siswa untuk memperlihatkan kemahirannya di depan umum, 11) Mengurangi akibat yang tidak menyenangkan dan keterlibatan siswa dalam kegiatan belajar, 12) Memahami iklim sosial dalam sekolah, 13) Memanfaatkan kewibawaan guru secara tepat, 14) Memperpadukan motif-motif yang kuat, 15) Memperjelas tujuan belajar yang hendak dicapai, 16) Merumuskan tujuan-tujuan sementara, 17) Memberitahukan hasil kerja yang telah dicapai, 18) Membuat suasana persaingan yang sehat di antara para siswa, 19) Mengembangkan persaingan dengan diri sendiri, dan 20) Memberikan contoh yang positif.

Menurut Uno (2014:23), indikator motivasi belajar dapat diklasifikasikan sebagai berikut: 1) Adanya hasrat dan keinginan berhasil, 2) Adanya dorongan dan kebutuhan dalam belajar, 3) Adanya harapan dan cita-cita masa depan, 4) Adanya penghargaan dalam belajar, 5) Adanya kegiatan yang menarik dalam belajar, 6) Adanya lingkungan belajar yang kondusif.

\section{Disiplin Belajar}

Prijodarminto (dalam Tu'u, 2004: 31) menyatakan bahwa siswa yang memiliki disiplin belajar akan menunjukkan kesiapannya dalam mengikuti pelajaran dalam kelas, mengerjakan tugas-tugas di rumah. Sebaliknya, siswa yang kurang disiplin belajar maka tidak menunjukkan kesiapan dalam mengikuti pelajaran, tidak mengerjakan tugas-tugas, suka membolos, tidak mengerjakan pekerjaan rumah dan tidak memiliki kelengkapan belajar. Apabila para siswa memiliki kedisiplinan yang tinggi maka semua kegiatan yang dilakukan akan tertata dengan rapi 
dan mendapatkan hasil yang memuaskan. Sifat disiplin ada dalam diri setiap orang yang ingin mendapatkan hasil belajar yang baik.

Untuk mengukur tingkat disiplin belajar siswa diperlukan indikator-indikator mengenai disiplin belajar. Menurut Moenir (2010:95) indikator - indikator yang dapat digunakan untuk mengukur tingkat disiplin belajar ekonomi siswa, yaitu: a) Disiplin waktu, meliputi: 1) Tepat waktu dalam belajar, mencakup datang dan pulang sekolah tepat waktu, mulai dan selesai belajar di sekolah tepat waktu dan memulai belajar kembali di rumah, 2) Hadir di dalam kegiatan pembelajaran, 3)Menyelesaikan tugas sesuai waktu yang ditetapkan. b) Disiplin perbuatan, meliputi: 1) Patuh terhadap tata tertib sekolah, 2) Rajin belajar, 3) Mandiri dalam belajar, 4) Jujur dan 5) Tingkah laku yang menyenangkan.

\section{Lingkungan Teman Sebaya}

Pendapat Slameto (2013:71) bahwa "pengaruh-pengaruh dari teman bergaul siswa lebih cepat masuk dalam jiwanya daripada yang kita duga. Teman bergaul yang baik akan berpengaruh baik terhadap siswa, begitu juga sebaliknya, teman bergaul yang tidak baik pasti berpengaruh tidak baik juga". Begitu juga dalam belajar, jadi apabila siswa berteman atau bergaul dengan siswa yang rajin maka siswa tersebut akan terbawa rajin, begitu juga sebaliknya apabila siswa bergaul dengan teman yang pemalas, tentunya ini akan berakibat siswa tersebut juga menjadi malas yang tentunya hal ini akan berpengaruh pada prestasi siswa.

Indikator teman sebaya terdiri dari: 1) interaksi sosial di lingkungan teman sebaya, 2) Keterlibatan individu dalam berinteraksi, 3) dukungan teman sebaya, 4) menjadi teman belajar siswa, dan 5) meningkatkan harga diri siswa.

\section{Kerangka Berpikir}

Lingkungan teman sebaya memberikan dorongan atau motivasi untuk belajar misalnya membuat kelompok belajar atau siswa menjadikan temannya untuk bertanya tentang pelajaran yang tidak dipahami akan berdampak positif terhadap hasil belajar ekonomi. Dapat disimpulkan bahwa motivasi belajar, disiplin belajar dan lingkungan teman sebaya memiliki kontribusi terhadap hasil belajar siswa di sekolah, sehingga tidak dapat diabaikan begitu saja. Dengan demikian, diperoleh pula gambaran model konseptual pengaruh motivasi belajar, disiplin belajar, dan lingkungan teman sebaya terhadap hasilbelajar siswa. Berdasarkan teori di atas, maka dapat digambarkan model konseptual penelitian sebagai berikut:

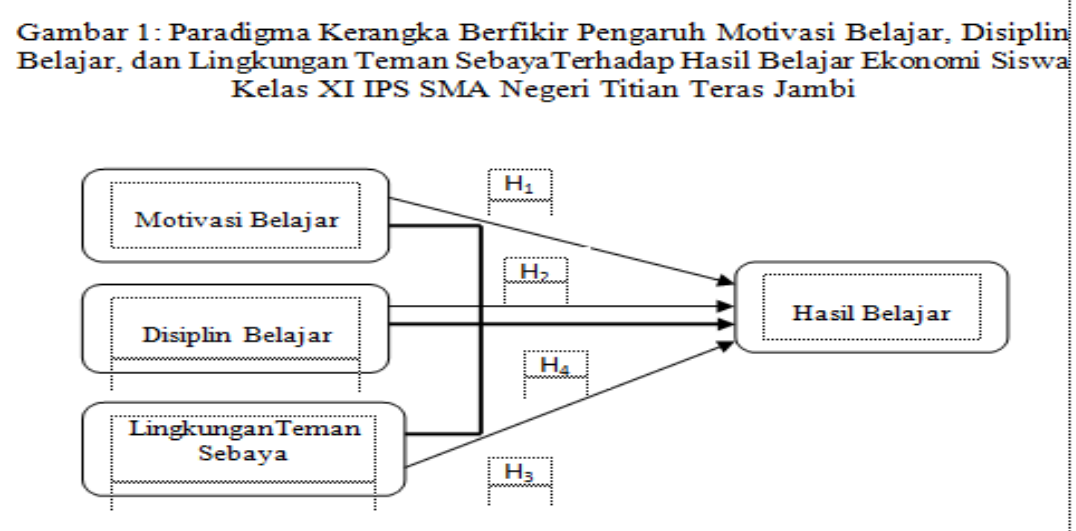

Dapat ditarik hipotesis penelitian yang merupakan jawaban sementara dari masalah penelitian yaitu sebagai berikut. 1) Terdapat pengaruh motivasi belajar terhadap hasil belajar, 2) Terdapat pengaruh disiplin belajar terhadap hasil belajar, 3) Terdapat pengaruh lingkungan teman 
sebayaterhadap hasil belajar, 4) Terdapat pengaruh motivasi belajar, disiplin belajar, lingkungan teman sebaya terhadap hasil belajar.

\section{METODE PENELITIAN}

Penelitian ini menggunakan pendekatan kuantitatif bersifat deskriptif dengan jenis penelitian ekplanatori untuk menjelaskan ada tidaknya pengaruh dan jika ada pengaruh seberapa besar pengaruh variabel bebas motivasi belajar $\left(\mathrm{X}_{1}\right)$, disiplin belajar $\left(\mathrm{X}_{2}\right)$, dan lingkungan teman sebaya $\left(\mathrm{X}_{3}\right)$ terhadap variabel terikat hasil belajar $(\mathrm{Y})$. Sampel penelitian ini sebanyak 72 siswa kelas XI IPS SMAN Titian Teras yang beralamat di Jl. Lintas Jambi - Muara Bulian Km. 21, Pijoan.

\section{HASIL DAN PEMBAHASAN}

\section{Hasil Penelitian}

Hasil penelitian menunjukkan bahwa nilai tertinggi sebesar 98 dan nilai terendah sebesar 68, mean sebesar 77.54 pada kategori cukup. Sehingga dapat disimpulkan bahwa pada variabel hasil belajar pada siswa IPS SMAN Titian Teras berada pada kategori cukup. Uji asumsi klasik yang dilakukan pada penelitian ini yaitu uji normalitas didapatkan bahwa semua variabel di dalam penelitian ini dinyatakan normal karena nilai Sig 0,20. Karena nilai Sig >0,05. Kemudian uji homogenitas dengan standar ukuran dikatakan homogen apabila nilai sig > 0.05 maka hasil penelitian ini menemukan bahwa: (1) Motivasi belajar dan hasil belajar memperoleh tingkat sig. $0.589>0.05$ maka dinyatakan homogen. (2) Disiplin belajar dan hasil belajar memperoleh tingkat sig. $0.085>0.05$ maka dinyatakan homogen. (3) Lingkungan teman sebaya dan hasil belajar memperoleh tingkat sig. $0.174>0.05$ maka dinyatakan homogen. Dari hasil di atas dapat disimpulkan bahwa seluruh variabel dinyatakan homogen karena nilai sig. > 0.05. Kemudian uji multikolinieritas semua model regresi ini tidak ditemukan gejala multikolinearitas nilai tolerance variabel motivasi belajar sebesar 0.777 $>0.1$ atau nilai VIF sebesar $1.286<10$. Selanjutnya uji heterokedastisitas variabel motivasi belajar $\left(\mathrm{X}_{1}\right)$ tidak mengalami heterokedastisitas dilihat dari Nilai Sig. sebesar 0.348> 0.05. terakhir uji autokorelasi bahwa dengan nilai sig. 0.05 diperoleh d $=1.425<\mathrm{dl}=1.5323$ sehingga dapat disimpulkan bahwa tidak terdapat auto korelasi antar variabel.

\section{Uji Regresi Linear Berganda}

Untuk melihat hasil uji regresi linier berganda motivasi belajar $\left(\mathrm{X}_{1}\right)$, disiplin belajar $\left(\mathrm{X}_{2}\right)$, dan lingkungan teman sebaya $\left(\mathrm{X}_{3}\right)$ terhadap hasil belajar pada siswa kelas XI IPS SMAN Titian Teras dapat dilihat pada tabel di bawah.

Tabel 1

Hasil Uji Regresi Linier Berganda Motivasi Belajar, Disiplin Belajar, dan Lingkungan Teman Sebaya Terhadap Hasil Belajar Coefficients $^{\mathrm{a}}$

\begin{tabular}{|c|c|c|c|c|c|c|}
\hline \multirow{2}{*}{\multicolumn{2}{|c|}{ Model }} & \multicolumn{2}{|c|}{ Unstandardized Coefficients } & \multirow{2}{*}{$\begin{array}{c}\begin{array}{c}\text { Standardized } \\
\text { Coefficients }\end{array} \\
\text { Beta }\end{array}$} & \multirow[b]{2}{*}{$\mathrm{t}$} & \multirow[b]{2}{*}{ Sig. } \\
\hline & & $\mathrm{B}$ & Std. Error & & & \\
\hline 1 & (Constant) & 5.551 & 13.152 & & .422 & .674 \\
\hline & MotivasiBelajar & .400 & .107 & .385 & 3.726 & .000 \\
\hline & DisiplinBelajar & .296 & .111 & .283 & 2.671 & .009 \\
\hline
\end{tabular}




\begin{tabular}{|c|c|c|c|c|c|}
\hline Lingkungan & .334 & .137 & .265 & 2.434 & .018 \\
\hline R Square & .373 & & & & \\
\hline F Hitung & 13.498 & & & & \\
\hline$\overline{F S i g}$ & .000 & & & & \\
\hline
\end{tabular}

a. Dependent Variable: HasilBelajar

Sumber: Data olahan Peneliti

Berdasarkan data pada tabel di atas menunjukkan bahwa terdapat pengaruh motivasi belajar terhadap hasil belajar sebesar sebesar 0. 334 dengan nilai signifikasi 0.000. Dengan persaman $\mathrm{Y}$ $=\mathrm{a}+\mathrm{bX} \mathrm{X}_{1}+\mathrm{bX}_{2}+\mathrm{bX} \mathrm{X}_{3}+\mathrm{e}$, atau $\mathrm{Y}=5.551+0.400 \mathrm{X}_{1}+0.296 \mathrm{X}_{2}+0.334 \mathrm{X}_{3}+\mathrm{e}$, yang berarti setiap penambahan hasil belajar 1 maka akan berpengaruh terhadap motivasi belajar sebesar 0 . 334.

\section{Pengujian Hipotesis Pertama}

Secara parsial dari nilai output motivasi belajar di atas dapat diketahui hasil Uji t yaitu sebesar 3.726 sedangkan nilai $t$ tabel $=1.666$. Maka nilai $t$ hitung $>t$ tabel yaitu sebesar 3.726>1.666 berarti terdapat pengaruh motivasi belajar terhadap hasil belajar dengan nilai signifikan motivasi belajar $\left(\mathrm{X}_{1}\right)$ sebesar $0.000<0.05$ atau dapat dinyatakan signifikan dengan pengaruh motivasi belajar terhadap hasil belajar sebesar 38,5\%.Maka dapat disimpulkan bahwa hipotesis nol ditolak: terdapat pengaruh motivasi belajar terhadap hasil belajar pada siswa kelas XI IPS SMAN Titian Teras.

\section{Pengujian Hipotesis Kedua}

Secara parsial dari nilai output disiplin belajar di atas dapat diketahui hasil Uji t yaitu sebesar 2.671 sedangkan nilai $\mathrm{t}_{\text {tabel }}=1.666$. maka nilai $\mathrm{t}$ hitung $>\mathrm{t}$ tabel yaitu sebesar 2.671>1.666 berarti terdapat pengaruh disiplin belajar terhadap hasil belajar dengan nilai signifikan motivasi belajar $\left(\mathrm{X}_{1}\right)$ sebesar $0.009<0.05$ atau dapat dinyatakan signifikan dengan pengaruh disiplin belajar terhadap hasil belajar sebesar 28,3\%. Maka dapat disimpulkan bahwa hipotesis nol ditolak : terdapat pengaruh disiplin belajar terhadap hasil belajar pada siswa kelas XI IPS SMAN Titian Teras.

\section{Pengujian Hipotesis Ketiga}

Secara parsial dari nilai output lingkungan teman sebaya di atas dapat diketahui hasil Uji t yaitu sebesar 2.434 sedangkan nilai $\mathrm{t}_{\text {tabel }}=1.666$. maka nilai $\mathrm{t}$ hitung $>\mathrm{t}$ tabel yaitu sebesar 2.434> 1.666 berarti terdapat pengaruh motivasi belajar terhadap hasil belajar dengan nilai signifikan motivasi belajar $\left(\mathrm{X}_{1}\right)$ sebesar $0.018<0.05$ atau dapat dinyatakan signifikan dengan pengaruh motivasi belajar terhadap hasil belajar sebesar 26,5\%.Maka dapat disimpulkan bahwa hipotesis nol ditolak : terdapat pengaruh lingkungan teman sebaya terhadap hasil belajar pada siswa kelas XI IPS SMAN Titian Teras.

Pengaruh dominan variabel independen terhadap variabel dependen dapat dilihat melalui absolute standardized coefficient yang paling besar. Hasil estimasi yang tertera pada tabel di atas dapat diketahui bahwa variabel independen yang memiliki standardized coefficientyang paling besar terhadap nilai hasil belajar adalah motivasi belajar sebesar 0.385 atau 38,5\%. Dengan demikian motivasi belajar merupakan variabel yang paling berpengaruh atau memiliki pengaruh yang paling dominan terhadap hasil belajar. 


\section{Pengujian Hipotesis Keempat}

Berdasarkan tabel di atas diketahui bahwa terdapat pengaruh sebesar 0.373 pada nilai signifikansi $\mathrm{F}$ sebesar $0.000<0.05$ atau dapat dilihat pada nilai $\mathrm{F}$ hitung sebesar $13.498>2.73$. Berdasarkan tabel interpretasi koefisien regresi sebesar 0.373termasuk dalam kategori cukup. Sehingga dapat disimpulkan terdapat pengaruh yang cukup dan signifikan secara simultan motivasi belajar $\left(\mathrm{X}_{1}\right)$, disiplin belajar $\left(\mathrm{X}_{2}\right)$, dan lingkungan teman sebaya $\left(\mathrm{X}_{3}\right)$ terhadap hasil belajar pada siswa kelas XI IPS SMAN Titian Teras.Pengaruh motivasi belajar, disiplin belajar dan lingkungan belajar terhadap hasil belajar berpengaruh sebesar 37.3\% yang berarti masih banyak faktor lain yang mempengaruhi hasil belajar yaitu sebesar 62,7\% yang tidak diteliti oleh penulis misalnya faktor kecerdasan siswa itu sendiri, daya tangkap atau pemahaman siswa, faktor lingkungan keluarga dan masih banyak faktor lainnya.

\section{PEMBAHASAN}

Berdasarkan analisis data yang telah dilakukan, diketahui bahwa terdapat pengaruh secara simultan (bersama-sama) motivasi belajar, disiplin belajar, dan lingkungan teman sebaya terhadap hasil belajar. Diketahui bahwa terdapat pengaruh sebesar 0.373 pada nilai signifikansi $\mathrm{F}$ sebesar $0.000<0.05$ atau dapat dilihat pada nilai $F$ hitung sebesar 13.498> 2.73. Berdasarkan tabel interpretasi koefisien regresi sebesar 0.373 termasuk dalam kategori cukup. Sehingga dapat disimpulkan terdapat pengaruh yang cukup dan signifikan secara simultan motivasi belajar $\left(\mathrm{X}_{1}\right)$, disiplin belajar $\left(\mathrm{X}_{2}\right)$, dan lingkungan teman sebaya $\left(\mathrm{X}_{3}\right)$ terhadap hasil belajar pada siswa kelas XI IPS SMAN Titian Teras.Pengaruh motivasi belajar, disiplin belajar dan lingkungan belajar terhadap hasil belajar berpengaruh sebesar 37,3\% yang berarti masih banyak faktor lain yang berpengaruh terhadap hasil belajaryaitu sebesar $62,7 \%$ yang tidak diteliti oleh penulis misalnya faktor kecerdasan siswa itu sendiri, daya tangkap atau pemahaman siswa, faktor lingkungan keluarga dan masih banyak faktor lainnya.

Secara parsial motivasi belajar memberikan pengaruh sebesar 38,5\%, disiplin belajar $28,3 \%$ dan lingkungan teman sebaya sebesar 26,5\%. Kontribusi tersebut menunjukan bahwa motivasi belajar dan disiplin belajar yang tinggi serta lingkungan teman sebaya yang baik akan membantu meningkatkan hasil belajar siswa. Dari data tersebut menunjukkan bahwa motivasi belajar lebih dominan memberikan kontribusi terhadap hasil belajar siswa daripada disiplin belajar dan lingkungan teman sebaya.

Berdasarkan hasil analisis data, secara simultan menunjukkan bahwa terdapat pengaruh motivasi belajar, disiplin belajar, dan lingkungan teman sebaya terhadap hasil belajar siswa kelas XI IPS SMAN Titian Teras. Adanya motivasi dan disiplin belajar dalam diri siswa tersebut sangat penting karena dengan adanya motivasi, disiplin dan lingkungan teman sebaya akan mendorong siswa untuk memiliki semangat dalam belajar dan melakukan suatu kegiatan yang akan menggerakkan diri dalam belajar untuk mencapai tujuan.

Sesuai dengan pendapat yang dikemukakan oleh Kompri (2015: 233) tentang pentingnya motivasi dalam belajar.Jika berdasarkan jurnal oleh Georgeta Panisoara, Nicoleta Duta, dan IonOvidiu Panisora (2015) yang berjudul "The influence of reasons approving on student motivation for earning" yang menyatakan bahwa berdasarkan data tentang pendapat siswa terkait persetujuan sosial motivasi belajar, motivasi untuk mencapai hasil yang baik dengan persetujuan sosial, motivasi untuk melakukan yang lebih baik dengan antusiasme, adanya persaingan serta sikap positif, jadi penting adanya peningkatan motivasi belajar untuk meningkatkan hasil belajar yang maksimal.

Hal tersebut juga relevan dengan penelitian yang dilakukan oleh Stevani (2016) dalam 
jurnalnya menyatakan bahwa motivasi berpengaruh signifikan terhadap hasil belajar dan motivasi berada pada kategori cukup. Selain itu berdasarkan hasil penelitian dari jurnal Zuhaira dan Subkhan (2015) juga membuktikan bahwa ada pengaruh motivasi belajar terhadap hasil belajar. Hal tersebut hasilnya relevan dengan hasil penelitian yang dilakukan penulis.

Selain disebabkan oleh motivasi belajar, hasil belajar juga dipengaruhi oleh disiplin belajar. Berdasarkan hasil penelitian menunjukkan hipotesis yang menyatakan ada pengaruh disiplin belajar terhadap hasil belajar siswa kelas XI IPS SMAN Titian Teras. Hal ini sesuai dengan pendapat yang dikemukakan oleh Tu'u (2008: 37) bahwa disiplin memunculkan kesadaran diri siswa sehingga siswa akan berhasil dalam belajar, tanpa disiplin pembelajaran kurang kondusif bagi pembelajaran, dengan disiplin merupakan jalan bagi siswa untuk sukses dalam belajar. Jadi, dengan adanya sikap disiplin dapat meningkatkan hasil belajar siswa.

Hasil tersebut relevan dengan penelitian yang dilakukan oleh Ayuni Dewi Megawati (2015), dalam penelitian tersebut hasilnya menunjukkan disiplin belajar berpengaruh terhadap hasil belajar. Kemudian hasil penelitian ini juga relevan dengan hasil penelitian yang dilakukan oleh peneliti lain yang tertuang dalam jurnal. Berdasarkan hasil penelitian dalam jurnal yang ditulis oleh Ryan dan Ade (2018) hasil penelitiannya menyatakan bahwa ada pengaruh positif dan signifikan disiplin belajar terhadap hasil belajar siswa. Selain itu berdasarkan hasil penelitian yang tertuang dalam jurnal oleh Imam Toha dan Dwi Wulandari (2016) yang berjudul "The Effect of Parents Attention and Learning Dicipline on Economics Learning Outcomes” dengan hasil penelitian menyatakan bahwa ada pengaruh positif pada disiplin belajar terhadap hasil belajar pada mata pelajaran ekonomi.

Lingkungan teman sebaya merupakan lingkungan dimana terjadinya suatu interaksi yang intensif dan cukup teratur yang mempunyai kesamaan dalam usia dan status, yang memberikan pengaruh positif maupun negatif yang dikarenakan interaksi didalamnya. Hasil penelitian ini diperkuat dengan kajian teori, menurut Slameto (2013: 54) terdapat faktor-faktor yang mempengaruhi hasil belajar yang digolongkan menjadi dua golongan yaitu faktor internal dan eksternal. Lingkungan teman sebaya merupakan faktor eksternal yang dapat memengaruhi hasil belajar.

\section{KESIMPULAN DAN SARAN}

Kesimpulan: 1) Motivasi belajar berpengaruh terhadap hasil belajar pada siswa kelas XI IPS SMAN Titian Teras. Secara parsial menunjukkan bahwa terdapat pengaruh motivasi belajar terhadap hasil belajar, nilai t hitung > t tabel sebesar 3.726> 1.666. Hasil analisis deskripsi motivasi belajar siswa beradapada tingkatan tinggi. Ini berarti semakin tinggi motivasi belajar siswa maka akan mengakibatkan hasil belajar yang tinggi pula. 2) Disiplin belajar berpengaruh terhadap hasil belajar pada siswa kelas XI IPS SMAN Titian Teras. Secara parsial menunjukkan bahwa terdapat pengaruh disiplin belajar terhadap hasil belajar, nilai $\mathrm{t}$ hitung $>\mathrm{t}$ tabel sebesar 2.671> 1.666. Hasil analisis deskripsi disiplin belajar siswa berada pada tingkatan tinggi. Ini berarti semakin tinggi disiplin belajar siswa maka akan mengakibatkan hasil belajar yang tinggi pula. 3) Lingkungan teman sebaya berpengaruh terhadap hasil belajar pada siswa kelas XI IPS SMAN Titian Teras. Secara parsial menunjukkan bahwa terdapat pengaruh lingkungan teman sebaya terhadap hasil belajar, nilai $t$ hitung $>t$ tabel sebesar 2.434> 1.666. Hasil analisis deskripsi lingkungan teman sebaya berada pada tingkatan baik. Ini berarti semakin baik atau semakin kondusif lingkungan teman sebaya maka akan semakin baik pula hasil belajar yang diperoleh siswa tersebut. 4) Motivasi belajar, disiplin belajar, dan lingkungan teman sebaya berpengaruh simultan terhadap hasil belajar pada siswa kelas XI IPS SMAN Titian Teras, nilai F hitung $>\mathrm{F}$ 
tabel sebesar $13.498>$ 2.73. Motivasi belajar memiliki pengaruh paling besar terhadap hasil belajar.

Saran: Bagi peneliti lanjutan dapat dijadikan masukan ataupun dapat menambah bahan kajian untuk memperluas variabel lain diluar variabel yang digunakan dalam penelitian ini selain motivasi belajar, disiplin belajar, dan lingkungan teman sebaya, karena pada dasarnya masih banyak faktor yang berpengaruh terhadap hasil belajar seperti faktor internal yang terdiri dari kesehatan, kecerdasan, keadaan tubuh, motivasi, minat, bakat, perhatian, motif dan lain-lain serta faktor eksternal seperti lingkungan alam, lingkungan sosial, lingkungan keluarga, guru dan cara mengajarnya, media pembelajaran dan sebagainya.

\section{DAFTAR RUJUKAN}

Ayuni, Dewi. 2015. Pengaruh Minat dan Disiplin Belajar terhadap Hasil Belajar Mengetik Manual Siswa Kelas XI Kompetensi Administrasi Perkantoran SMK Muhammadiyah I Prambanan Klaten. Yogyakarta

Dalyono. 1997. Psikologi Pendidikan. Jakarta: PT Rineka Cipta

Djamarah, Syaiful Bahri. 2011. Psikologi Belajar. Jakarta: Rineka Cipta

Hamdu, Ghullam. L. A. 2011. Pengaruh Motivasi Belajar Siswa Terhadap Prestasi Belajar Ipa. Jurnal Penelitian Pendidikan vol. 12 No. 1, http://www.jurnal.upi.edu/file/8Ghullam_Hamdu.pdf

Hamalik, Oemar. 2003. Prosedur Belajar Mengajar. Jakarta: Bumi Aksara

Imam Thoha, Dwi Wulandari. (2016). The Effect of Parents Attention and Learning Dicipline on Economics Learning Outcomes. IOSR Journal of Research \& Method in Education (IOSRJRME). E-ISSN: 2320-7388, p-ISSN: 2320-737X Volume 6, Issue 2 Ver. Diambil pada 30 November 2019, dari www.iosrjournals.org

Kompri. 2015. Motivasi Pembelajaran Perspektif Guru dan Siswa. Bandung. PT Remaja Rosdakarya

Moenir. 2010. Masalah-masalah dalam belajar. Yogyakarta: Pustaka Pelajar

Ryan, P \& Ade, R. 2018. Pengaruh Disiplin Belajar, Lingkungan Keluarga, dan Motivasi Belajar Terhadap Hasil Belajar Siswa. Economic Education Analysis Journal.

Sardiman. 2001. Interaksi dan Motivasi Belajar Mengajar. Jakarta: PT Raja Grafindo Persada

Slameto. 2013. Belajar dan Faktor-faktor yang mempengaruhinya. Jakarta: Rineka Cipta

Sudjana, Nana. 2005. Penilaian Hasil Proses Belajar Mengajar. Bandung: PT Remaja Rosdakarya

Stevani. 2016. Analisis Pengaruh Motivasi Belajar Terhadap Hasil Belajar Ekonomi Siswa Kelas

X SMK Negeri 5 Padang

Tu’u, Tulus. 2004. Peran Disiplin Pada Perilaku dan Prestasi Siswa. Jakarta: Grasindo.

. . . . 2008. Peran Disiplin pada perilaku dan Prestasi Belajar. Jakarta: Grasindo

Uno, Hamzah B. 2014. Teori Motivasi dan Pengukurannya. Jakarta: Bumi Aksara

Uno, H.B. 2015. Teori Motivasi dan Pengukurannya Analisis dibidang Pendidikan. Jakarta: Bumi Aksara

Zuhaira, L.K \& Subkhan. (2015). Pengaruh Motivasi Belajar dan Kedisiplinan Belajar Terhadap Prestasi Belajar Siswa Kelas XI IPS SMKN 3 Pati. Economic Education Analysis Journal 